\title{
Contribution of Chloride Channel Activation to the Elevated Muscular Tone of the Pulmonary Artery in Monocrotaline-Induced Pulmonary Hypertensive Rats
}

\author{
Hiroshi Nakazawa, Masatoshi Hori, Takahisa Murata, Hiroshi Ozaki* and Hideaki Karaki \\ Department of Veterinary Pharmacology, Graduate School of Agriculture and Life Sciences, The University of Tokyo, \\ Yayoi 1-1-1, Bunkyo-ku, Tokyo 113-8657, Japan
}

Received November 20, 2000 Accepted April 13, 2001

\begin{abstract}
In monocrotaline-treated rat pulmonary artery from which endothelium was removed, greater spontaneous muscular tone was observed under resting conditions than in vehicle-treated artery. The aim of the present study was to show the possible contribution of $\mathrm{Cl}^{-}$channels in the mechanism of the elevated tone. Verapamil almost completely inhibited the elevated spontaneous muscular tone by decreasing $\left[\mathrm{Ca}^{2+}\right]_{\text {i. }}$. The elevated muscular tone was also inhibited by 4,4'-diisothiocyanato-stilbene-2,2'-disulfonic acid (DIDS), a $\mathrm{Cl}^{-}$channel inhibitor. After the inhibition of muscular tone by DIDS, verapamil did not induce further relaxation. Quantitative RT-PCR analysis indicated that the mRNA levels of $\mathrm{ClC} 3$ and $\mathrm{Ca}^{2+}$-activated $\mathrm{Cl}^{-}$ channels did not change in the pulmonary hypertensive pulmonary artery from those of vehicle-treated rats. These results suggest that the elevated muscular tone observed in the monocrotaline-induced hypertensive pulmonary artery is due to membrane depolarization of smooth muscle cells and that this phenomenon might be mediated by the activation of DIDS-sensitive $\mathrm{Cl}^{-}$channels.
\end{abstract}

Keywords: $\mathrm{Cl}^{-}$channel, Pulmonary hypertension, Smooth muscle, Vasoconstriction, Monocrotaline

Pulmonary hypertension is characterized by an elevation of pulmonary blood pressure without changing the systemic circulation. Major pathophysiological changes found in patients with this disease include right ventricular hypertrophy and pulmonary vascular remodeling. Because the chronic exposure of rats to a hypoxic environment or a single injection of monocrotaline (MCT), a plant toxin pyrrolizidine alkaloid, can mimic pulmonary hypertension with pathophysiological changes similar to those in humans, these rats have been widely used as an experimental model of pulmonary hypertension $(1-4)$.

Accumulating evidence indicates a potential role for endothelial dysfunction as an early event in pulmonary hypertension $(5-7)$. We have recently found that NOmediated arterial relaxation in the pulmonary artery from MCT-treated rats is impaired, although the expression of eNOS mRNA is increased in the MCT rat artery (8). We have further suggested in the report that the dissociation between eNOS expression and NO production is due to an inhibition of receptor-mediated $\mathrm{Ca}^{2+}$ metabolism in endothelial cells, as well as to an apparent decrease in the $\mathrm{Ca}^{2+}$

*Corresponding author. FAX: +81-3-5841-8183

E-mail: aozaki@mail.ecc.u-tokyo.ac.jp sensitivity of eNOS. The endothelium dysfunction also contributes to the induction of vascular remodeling, including increases in medial thickness and connective tissue (912).

Several pathophysiological changes in arterial smooth muscle cells have also been observed in the pulmonary hypertensive rat. The sensitivities to norepinephrine, prostaglandin and serotonin are also increased in the pulmonary artery of the hypertensive rat $(13,14)$. In addition, the amount of endothelin- 1 in the arterial tissue has also been reported to be increased $(15,16)$, and daily infusion of an $\mathrm{ET}_{\mathrm{A}}$-receptor blocker, BQ-123, has been shown to inhibit cardiopulmonary changes in the MCT-induced hypertensive rat (17). In contrast, Suzuki and Twarog (18) have observed that the membrane of pulmonary arterial cells isolated from the pulmonary hypertensive rat is depolarized in the resting state. Ito et al. (19) also reported that MCTtreatment depolarized smooth muscle membrane in the pulmonary arterial tissue. However, the mechanism of the membrane depolarization due to pulmonary hypertension remains unknown. The present study was undertaken to elucidate the mechanism for elevated membrane potential in the pulmonary artery of the MCT-induced pulmonary hypertensive rat. 


\section{MATERIALS AND METHODS}

\section{MCT-induced pulmonary hypertensive rats and tissue preparation}

MCT $(300 \mathrm{mg})$ was dissolved in $1.8 \mathrm{ml}$ of $1 \mathrm{M} \mathrm{HCl}$, followed by the addition of $3-4 \mathrm{ml}$ of distilled water. This solution was adjusted to $\mathrm{pH} 7.4$ with $1 \mathrm{M} \mathrm{NaOH}$ and brought to a volume of $15 \mathrm{ml}$ with distilled water (1). MCT $\left(60 \mathrm{mg} \cdot \mathrm{kg}^{-1}\right)$ or its vehicle was administered to 6-week-old male Sprague Dawley rats $(180-210 \mathrm{~g})$ as a single subcutaneous injection. Rats were housed with a 12:12-light-dark cycle and given water and standard rat chow ad libitum. All experiments were performed 21 days after the administration. Pulmonary hypertension was confirmed by right ventricular hypertension, as described by Nakazawa et al. (8). Rats were killed by a sharp blow to the neck and exsanguination. Heart and lungs were removed en bloc, and right and left extra-pulmonary arteries were dissected. Except as otherwise stated, endothelium was gently rubbed with a glass rod moistened with physiological salt solution (PSS).

\section{Solutions}

PSS, which contained $136.9 \mathrm{mM} \mathrm{NaCl}, 5.4 \mathrm{mM} \mathrm{KCl}$, $1.5 \mathrm{mM} \mathrm{CaCl} 2,1.0 \mathrm{mM} \mathrm{MgCl}_{2}, 5.5 \mathrm{mM}$ glucose and $5.0 \mathrm{mM}$ HEPES, was saturated with $100 \% \mathrm{O}_{2}$ at $37^{\circ} \mathrm{C}$. The $\mathrm{pH}$ was adjusted to $7.3-7.4$ with $1 \mathrm{M} \mathrm{NaOH}$ at $37^{\circ} \mathrm{C}$. The high $\mathrm{K}^{+}$solution $(72.7 \mathrm{mM})$ was made by replacing $\mathrm{NaCl}$ with equimolar $\mathrm{KCl}$. $\mathrm{Ca}^{2+}$-free solution was made by omitting $\mathrm{CaCl}_{2}$ and adding $0.5 \mathrm{mM}$ EGTA.

\section{Histology}

The pulmonary arteries isolated from vehicle- or MCTtreated rats were fixed in $10 \%$ neutral buffered formalin and embedded in paraffin. Four-micrometer-thick sections were stained with hematoxylin and eosin and then examined under a light microscope.

\section{Measurements of muscle force}

Pulmonary arteries without endothelium were cut into rings approximately 2-mm wide. Muscle tension was recorded isometrically under a resting tension of $10 \mathrm{mN}$. At the end of each experiment, $100 \mu \mathrm{M}$ papaverine was added to determine the basal tone $(0 \%)$.

\section{Simultaneous measurement of intracellular $\mathrm{Ca}^{2+}$ levels and muscle force}

Intracellular $\mathrm{Ca}^{2+}$ levels $\left(\left[\mathrm{Ca}^{2+}\right]_{\mathrm{i}}\right)$ were measured simultaneously with muscle contractions, as described by Ozaki et al. (20), using a fluorescent $\mathrm{Ca}^{2+}$ indicator, fura-PE3. Briefly, endothelium-denuded pulmonary arterial tissue (1-mm-wide) was incubated in PSS with a $10 \mu \mathrm{M}$ acetoxymethyl ester of fura-PE3 and $0.02 \%$ cremophor EL for
$3-4 \mathrm{~h}$ at $37^{\circ} \mathrm{C}$. Experiments were performed with a fluorimeter (CAF-110; Japan Spectroscopic, Tokyo), and the ratio of F340 to F380 (F340/380) was used as an indicator of $\left[\mathrm{Ca}^{2+}\right]_{\mathrm{i}}$. We took the ratio and muscle force under the resting condition to be $0 \%$ and that under the high $\mathrm{K}^{+}$stimulated condition to be $100 \%$.

\section{Quantitative RT-PCR}

Total RNA extraction and quantitative RT-PCR was performed by a previously described procedure (8). The oligonucleotide primers for $\mathrm{ClC} 3$ designed from rat $\mathrm{ClC} 3$ mRNA (D17521) were ACC AGC TAT AAT GGC TTT CC (sens) and CTA CCA CAA TCT CCA TTG GG (reverse). The oligonucleotide primers for $\mathrm{Ca}^{2+}$-activated $\mathrm{Cl}^{-}$channels (ClCA) designed from rat ClCA mRNA (AF077303) were ACT TCC GGT CTG ATA CCT AA (sens) and TTG GCC AGA ATT GCA ATG TA (reverse). The expected sizes of the PCR products for $\mathrm{ClC} 3$ and $\mathrm{ClCA}$ were 259 base pairs (bp) and $110 \mathrm{bp}$, respectively. The PCR products were electrophoresed on $2 \%$ agarose gel containing $0.1 \%$ ethidium bromide. We visualized detectable fluorescent bands with an ultraviolet (UV)-transilluminator and saved the image using FAS III (Toyobo, Tokyo).

\section{Drugs}

Drugs used were MCT, papaverine, verapamil, 4,4'diisothiocyanate-stilbene-2,2'-disulfonic acid (DIDS), IAA94 (Sigma, St. Louis, MO, USA); BQ-123 (Peptide Institute, Inc., Mino-shi); and fura-PE3 (Teflabs, Austin, TX, USA). RES-701-1 was generously donated by Kyowa Hakko Kogyo Co., Ltd. (Tokyo).

\section{Statistical analyses}

Results are expressed as means \pm S.E.M. Comparison between the control and test groups was performed by oneway analysis of variance (ANOVA) followed by Dunnett's multiple comparison test. Differences with $P$ values less than 0.05 were considered to be statistically significant.

\section{RESULTS}

Morphological change in the pulmonary artery of the MCT-induced pulmonary hypertensive rat

Pulmonary arteries of the vehicle- and MCT-treated rats were stained with hematoxylin and eosin and examined under a light microscope (Fig. 1A). Endothelial cells of vehicle- and MCT-treated arteries were located along the inner surface, which appeared to be intact in both preparations. In contrast, in the media layer in the hypertensive pulmonary artery, smooth muscle cell bodies and nuclei seemed to be swelling. Furthermore, thickenings of media and adventitia were observed in the pulmonary artery of MCT-treated rat. 
A

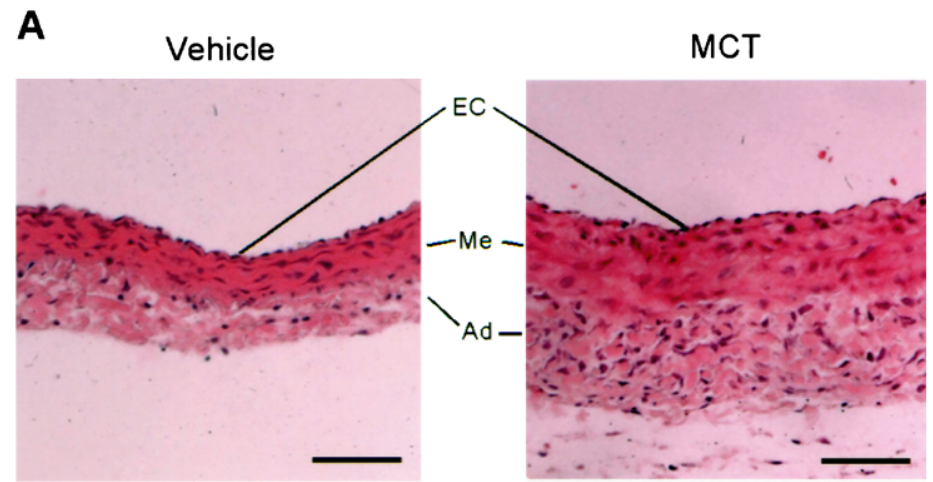

B
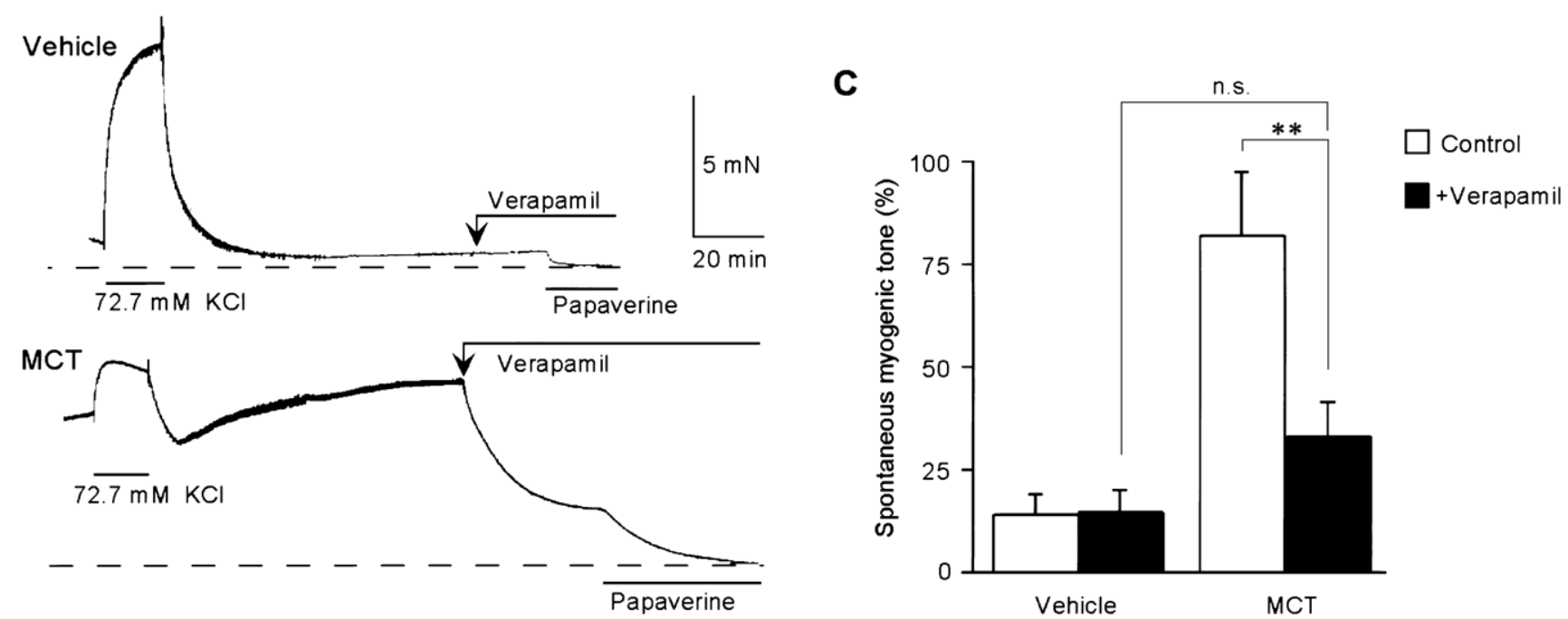

Fig. 1. Morphological and functional changes in pulmonary artery in the MCT-treated rat. A: Representative light micrographs of sections stained with hematoxylin and eosin in pulmonary artery. Left: Pulmonary artery isolated from the vehicle-treated rat. Right: Pulmonary artery isolated from MCT-treated rat at 21 days after injection of MCT. Scale bar $=100 \mu \mathrm{m}$. EC: endothelial cell, Me: media, Ad: adventitia. B: Effect of verapamil on spontaneous muscular tone in the pulmonary artery. Typical trace of the spontaneous muscular tone in the pulmonary artery of the vehicle-treated rat (upper trace) or MCT-treated rat (lower trace) is shown. C: The summarized results from panel $\mathrm{B}(\mathrm{n}=5$ each). Contractions elicited by $72.7 \mathrm{mM} \mathrm{KCl}$ and resting tension in the presence of $10 \mu \mathrm{M}$ verapamil and $100 \mu \mathrm{M}$ papaverine were taken as $0 \%$ and $100 \%$, respectively. $* *$ Significantly different from the control $(P<0.01)$.

Elevation of spontaneous active muscular tone in MCTtreated rats

In the endothelium-denuded, vehicle-treated rat pulmonary artery, $72.7 \mathrm{mM} \mathrm{KCl}$ induced a sustained contraction (Fig. 1B). In the resting state, the addition of $10 \mu \mathrm{M}$ verapamil had no appreciable effect on the basal tone. However, $100 \mu \mathrm{M}$ papaverine, a non-selective and potent inhibitor of smooth muscle contraction, slightly decreased the basal active tone. In contrast, in MCT-treated, endotheliumdenuded pulmonary artery, $72.7 \mathrm{mM} \mathrm{KCl}$ induced only a very small contraction compared to that in the vehicletreated rat. Furthermore, the addition of $10 \mu \mathrm{M}$ verapamil induced a greater decrease in the basal active tone far below the resting level, compared to that in the vehicletreated artery. Papaverine $(100 \mu \mathrm{M})$ further decreased the basal tone. Figure $1 \mathrm{C}$ provides a summary of the results shown in Fig. 1B. It is noted that the active muscular tonus in the vehicle- and MCT-treated rats was $13.6 \pm 5.1 \%$ $(\mathrm{n}=5)$ and $81.3 \pm 15.6 \%(\mathrm{n}=5)$, respectively, when the muscle tonus in the presence of both verapamil and papaverine was taken as $0 \%$ and a high $\mathrm{K}^{+}$-induced sustained contraction was taken as $100 \%$, respectively. The $\mathrm{ET}_{\mathrm{A}^{-}}$ receptor antagonist (BQ-123, $3 \mu \mathrm{M})$ and $\mathrm{ET}_{\mathrm{B}}$-receptor antagonist (RES701-1, $10 \mu \mathrm{M}$ ) appeared to have no effect on the spontaneous muscular tone.

\section{Effect of verapamil on cytosolic $\mathrm{Ca}^{2+}$ levels $\left(\left[\mathrm{Ca}^{2+}\right]_{i}\right)$}

Using a fura-PE3-loaded pulmonary arterial strip, we simultaneously measured $\left[\mathrm{Ca}^{2+}\right]_{\mathrm{i}}$ and muscle contractions (Fig. 2). In this series of experiments, $\left[\mathrm{Ca}^{2+}\right]_{\mathrm{i}}$ levels at 
resting and at high $\mathrm{K}^{+}$-stimulation were taken as $0 \%$ and $100 \%$, respectively, because papaverine interfered with the fluorescent intensity of fura-PE3. In the pulmonary artery from vehicle-treated rats, $10 \mu \mathrm{M}$ verapamil decreased the resting $\left[\mathrm{Ca}^{2+}\right]_{\mathrm{i}}$ and muscle force only by $7.8 \pm 2.1 \%$ and $7.4 \pm 1.8 \%(\mathrm{n}=5)$, respectively. In contrast, in the artery from the MCT-treated rat, $10 \mu \mathrm{M}$ verapamil decreased the resting $\left[\mathrm{Ca}^{2+}\right]_{\mathrm{i}}$ by $46.5 \pm 12.3 \%$, which was accompanied by a $27.6 \pm 7.3 \%(n=7)$ decrease in muscle force.

\section{Role of the $\mathrm{Cl}^{-}$channel in spontaneous muscular tone}

We examined the effects of $\mathrm{Cl}^{-}$channel blockers on spontaneous muscular tone and $24 \mathrm{mM} \mathrm{KCl-induced} \mathrm{contra-}$

A
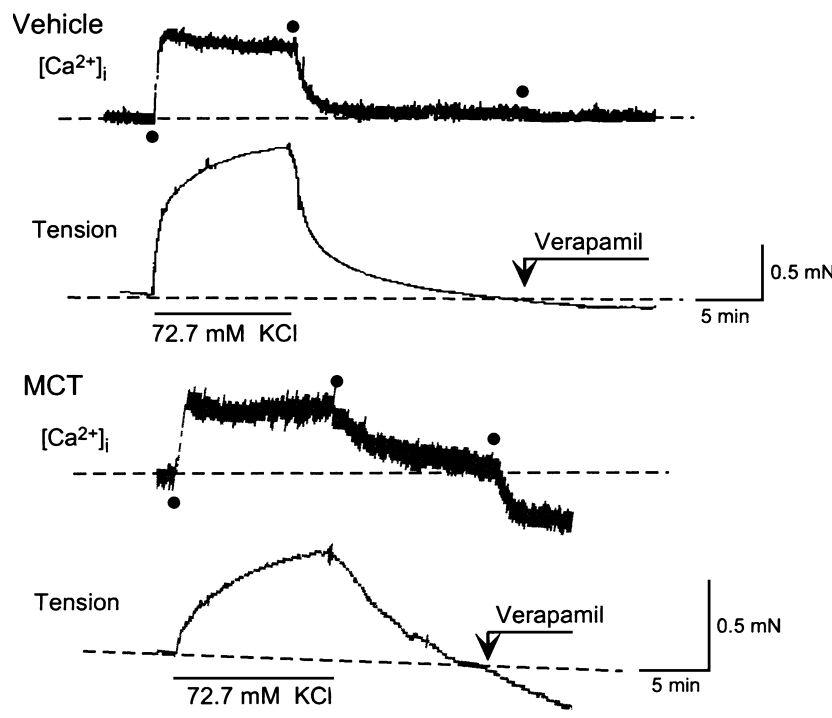

B

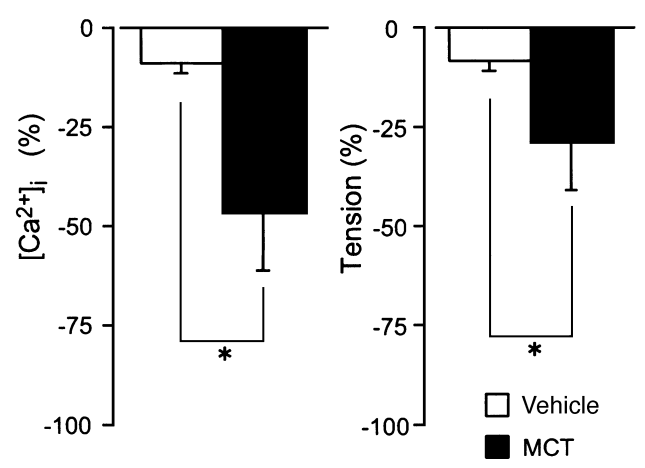

Fig. 2. Effect of verapamil on the muscular spontaneous tone and the cytosolic $\mathrm{Ca}^{2+}$ levels. A: Typical trace of $\left[\mathrm{Ca}^{2+}\right]_{\mathrm{i}}$ and muscle force in pulmonary artery loaded with fura-PE3 in the vehicle- or MCTtreated rat. After measuring the effects of $72.7 \mathrm{mM} \mathrm{KCl}$ on $\left[\mathrm{Ca}^{2+}\right]_{\mathrm{i}}$ and muscle force, the effects of $10 \mu \mathrm{M}$ verapamil on the muscular spontaneous tone and $\left[\mathrm{Ca}^{2+}\right]_{i}$ were examined. A typical trace out of five experiments is shown. B: The summarized results from panel A. Responses elicited by $72.7 \mathrm{mM} \mathrm{KCl}$ and the resting state were taken as $0 \%$ and $100 \%$, respectively. ${ }^{*}$ Significantly different from vehicletreated artery $(P<0.05)$. ctions. DIDS (100 and $300 \mu \mathrm{M}$ ) did not inhibit the $24 \mathrm{mM}$ $\mathrm{KCl}$-induced contraction in vehicle-treated and MCT-treated arteries, as shown in Fig. 3A (upper trace) and Fig. 3B. In contrast, DIDS inhibited the spontaneous active tone in MCT-treated artery in a concentration-dependent manner ( $n=7$, Fig. 3A lower trace), but it had no effect on the spontaneous tone in vehicle treated artery $(n=5$, data not shown). Verapamil $(10 \mu \mathrm{M})$, added in the presence of DIDS, had no effect on the spontaneous muscular tone. However, the addition of $100 \mu \mathrm{M}$ papaverine further decreased the spontaneous active tone, as shown in Fig. 3A (lower trace). Another $\mathrm{Cl}^{-}$channel blocker, IAA94 (100 and $300 \mu \mathrm{M}$ ), inhibited the high $\mathrm{K}^{+}$-induced contraction possibly through a nonspecific direct action on L-type $\mathrm{Ca}^{2+}$
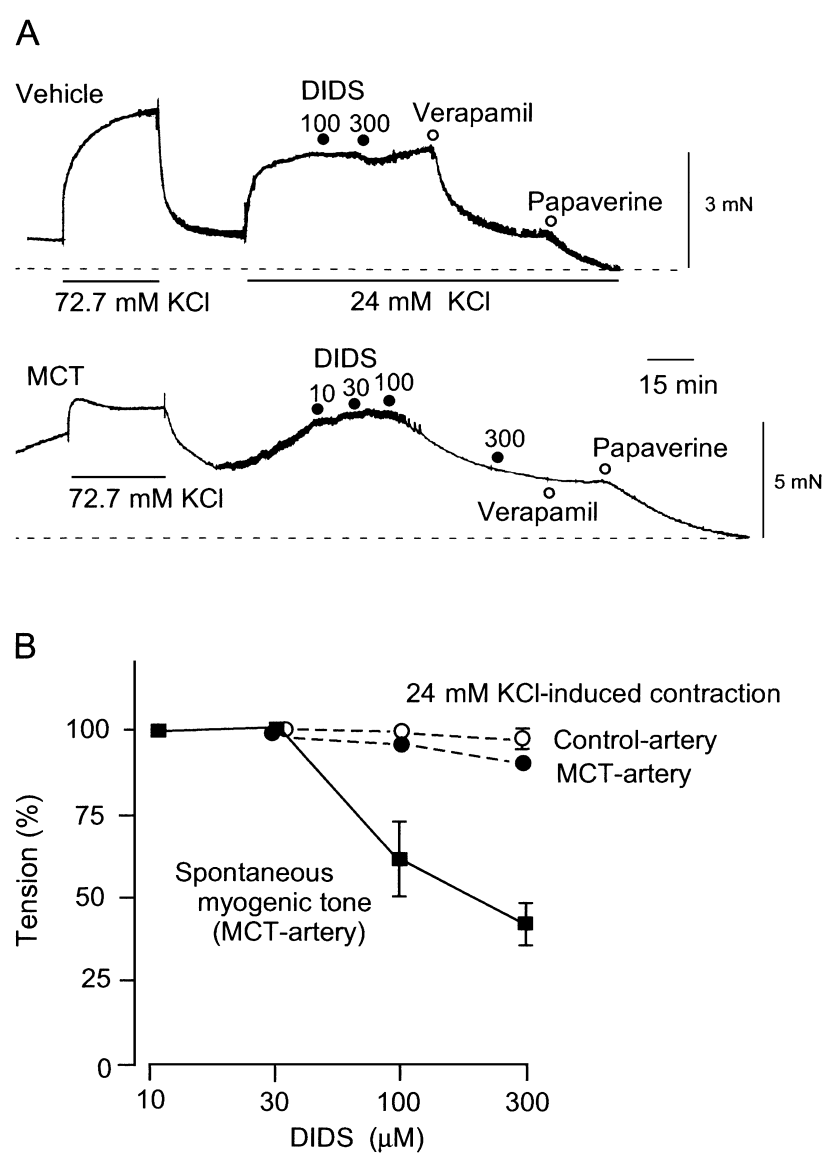

Fig. 3. Effect of DIDS on the $24 \mathrm{mM} \mathrm{KCl}$-induced contraction or the spontaneous muscular tone in pulmonary artery isolated from vehicle- or MCT-treated rat. In panel A, the upper trace shows the effects of $100-300 \mu \mathrm{M}$ DIDS on the $24 \mathrm{mM} \mathrm{KCl}$-induced contraction in the pulmonary artery from vehicle-treated rats. The lower trace shows the effects of $10-300 \mu \mathrm{M}$ DIDS on the spontaneous muscular tone of the hypertensive pulmonary artery from MCTtreated rat. The chart trace shows a typical trace out of five experiments. Panel B shows the concentration-response curve representing the effects of DIDS on the KCl-induced contractions in vehicletreated and MCT-treated arteries or the spontaneous muscular tone in MCT-treated arteries $(n=5$ each). 
channels $(n=5$, data not shown). Interference of the furaPE3 fluorescence by DIDS and IAA94 made it impossible for us to measure the change in $\left[\mathrm{Ca}^{2+}\right]_{\mathrm{i}}$ in the arteries.

We also examined the effect of DIDS and verapamil on resting tension in the aorta. Neither DIDS $(300 \mu \mathrm{M})$ nor verapamil $(10 \mu \mathrm{M})$ affected the resting tension in vehicletreated and MCT-treated aortae $(n=4$ each, data not shown).

We carried out quantitative RT-PCR analysis to examine the changes in $\mathrm{ClC} 3$ mRNA levels in the pulmonary arteries (Fig. 4A). The expressions of the housekeeping gene, GAPDH (308 bp), were identical between the arteries from vehicle- and MCT-treated rats. The levels of $\mathrm{ClC} 3$ mRNA (259 bp) expression were also identical in both preparations $(n=4)$. We also analyzed the expression levels of $\mathrm{ClCA}$, with our results indicating that the levels of $\mathrm{ClCA}$ mRNA expression did not differ between vehicle-treated and MCT-treated rats $(\mathrm{n}=3)$ (Fig. 4B).

\section{A. Vehicle}

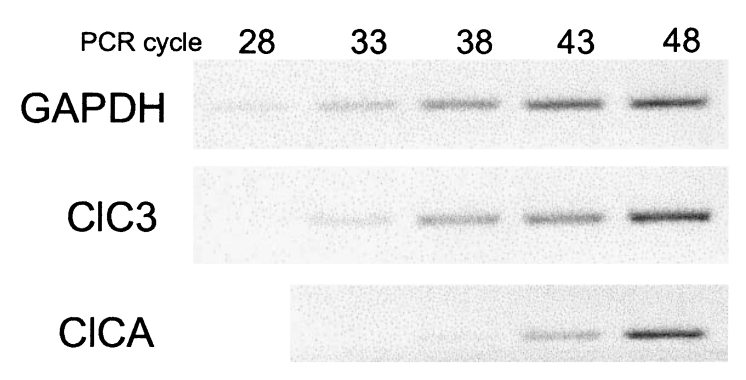

\section{B. MCT}

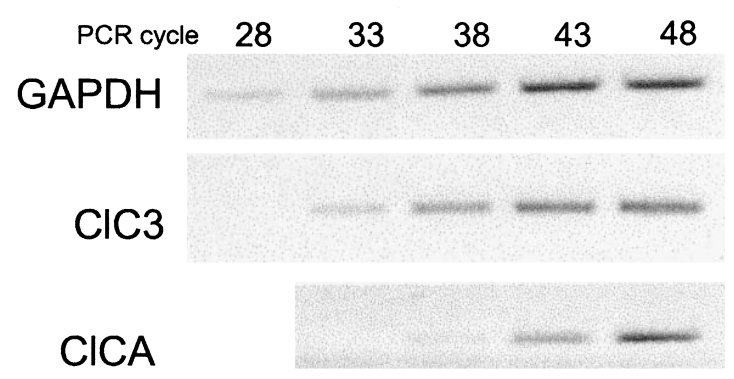

Fig. 4. Quantitative RT-PCR analysis of $\mathrm{ClC} 3$ mRNA (A) and ClCA mRNA (B) in the pulmonary artery of vehicle- and MCTtreated rat. A $1-\mu \mathrm{g}$ sample of total RNA from pulmonary artery of the vehicle- or MCT-treated rats was used in each RT-PCR analysis. Panel A shows the detection results for the RT-PCR products for GAPDH and $\mathrm{ClC} 3$ from $28 \mathrm{PCR}$-cycles to $48 \mathrm{PCR}$-cycles, respectively. Panel B shows the detection results for the RT-PCR products for GAPDH and ClCA from 28 PCR-cycles to 48 PCR-cycles, respectively. Typical results from 3-4 experiments are shown in the figure.

\section{DISCUSSION}

We have found in the present study that the main pulmonary artery isolated from MCT-induced pulmonary hypertensive rats exhibits greater muscular tone in the resting state. In addition, this tone is sensitive to verapamil, a voltage-sensitive $\mathrm{Ca}^{2+}$ channel blocker, and DIDS, a $\mathrm{Cl}^{-}$channel blocker.

Suzuki and Twarog (18) have reported that the membrane potential of the rat main pulmonary artery depolarizes at 8 days after exposure to hypoxia or 20 days after the injection of MCT. Ito et al. (19) also observed the membrane depolarization in MCT-treated pulmonary arterial tissue. Consistent with these observations, we observed elevated muscular tone in the hypertensive pulmonary artery at 21 days after MCT injection. Consistent with the report of Suzuki and Twarog (18), this muscular tone is associated with an increase in $\left[\mathrm{Ca}^{2+}\right]_{\mathrm{i}}$ that is inhibited by the voltagedependent $\mathrm{Ca}^{2+}$-channel blocker verapamil. Membrane stretch or an increase in transmural pressure causes a change in muscular tone in vascular smooth muscle cells (21). Several other studies have also revealed that the vascular spontaneous active tone is dependent on extracellular $\mathrm{Ca}^{2+}$, and the contraction is associated with membrane depolarization $(22-24)$. Recently, Nelson and coworkers (25) have shown that pressure-induced membrane depolarization and vasoconstriction are inhibited by $\mathrm{Cl}^{-}$ channel antagonists, whereas the ClCA channel inhibitor niflumic acid does not inhibit the contraction, suggesting that the activation of some types of $\mathrm{Cl}^{-}$channels, other than $\mathrm{ClCA}$, may be essential to inducing membrane depolarization of the cerebral arterial cells. More recently, it has been reported in the canine pulmonary artery that $\mathrm{ClC} 3$ is expressed and that the cell-swelling induced by decreasing external osmolarity is accompanied by an activation of the DIDS-sensitive $\mathrm{Cl}^{-}$channel in the pulmonary artery (26). The authors postulated that the $\mathrm{ClC} 3$ channel might contribute to the regulation of cell volume, resting membrane potential, and muscular tone. In the present study, the verapamil-sensitive spontaneous muscular tone in the hypertensive pulmonary artery was completely inhibited by DIDS. This result strongly supports the hypothesis that activation of the $\mathrm{ClC} 3$ channel or other DIDS-sensitive $\mathrm{Cl}^{-}$channels may contribute to the elevated spontaneous muscular tone.

Although we could have confirmed that $\mathrm{ClC} 3$ and $\mathrm{ClCA}$ are molecularly expressed in rat pulmonary artery, the quantitative RT-PCR analysis indicated that the expression of $\mathrm{ClC} 3 \mathrm{mRNA}$ or ClCA mRNA levels in the hypertensive pulmonary artery did not differ from that of the vehicletreated artery. This result suggests that the DIDS-sensitive membrane depolarization may not be mediated by the increase in the number of $\mathrm{ClC} 3$ or $\mathrm{ClCA}$, but may be 
mediated at the level of activity of these $\mathrm{Cl}^{-}$channels. Further examinations using the patch-clamp technique are necessary to clarify the change in activity of these $\mathrm{Cl}^{-}$ channels.

It has also been reported that tissue endothelin-1 levels are increased in the pulmonary artery of MCT-treated rat $(15,16)$. In addition, it has been reported that the daily infusion of $\mathrm{ET}_{\mathrm{A}}$-antagonist inhibits the cardiopulmonary changes produced by MCT-induced pulmonary hypertension (17). In the present study, however, $\mathrm{ET}_{\mathrm{A}}$ antagonist (BQ-123) and ET $_{B}$-receptor antagonist (RES701-1) had no effect on the spontaneous muscular tone in vitro, indicating that elevated levels of endothelin-1 might not be related to spontaneous muscular tone.

In conclusion, the elevated spontaneous muscular tone observed in the MCT-induced hypertensive pulmonary artery is due to membrane depolarization induced by activation of DIDS-sensitive $\mathrm{Cl}^{-}$channels.

\section{Acknowledgments}

The authors thank Dr. Jun Yamazaki (Fukuoka Dental College, Department of Pharmacology) for his useful discussions. This work was partly supported by a Grant-in-Aid for Scientific Research from the Ministry of Education, Science, Sports and Culture, Japan.

\section{REFERENCES}

1 Hayashi Y, Hussa JF and Lalich JJ: Cor pulmonale in rats. Lab Invest 16, 875 - 876 (1967)

2 Rabinovitch M, Gamble M, Nada AS, Miettinen OS and Reid L: Rat pulmonary circulation after chronic hypoxia: hemodynamic and structural features. Am J Physiol 236, H813 - H827 (1979)

3 Meyrick B, Gamble W and Reid L: Development of crotalaria pulmonary hypertension: hemodynamic and structural study. Am J Physiol 239, H692 - H702 (1980)

4 Ghodsi F and Will LJA: Changes in pulmonary structure and function induced by monocrotaline intoxication. Am J Physiol 240, H149 - H155 (1981)

5 Altiere RJ, Olson JW and Gillespie MN: Altered pulmonary vascular smooth muscle responsiveness in monocrotalineinduced pulmonary hypertension. J Pharmacol Exp Ther 236, $390-395(1985)$

6 Ito K, Nakashima T, Murakami K and Murakami T: Altered function of pulmonary endothelium following monocrotalineinduced lung vascular injury in rats. Br J Pharmacol 94, 1175 $1183(1988)$

7 Adnot S, Raffestin B, Eddahibi S, Braquet P and Chabrier P-E: Loss of endothelium-dependent relaxant activity in the pulmonary circulation of rats exposed to chronic hypoxia. J Clin Invest 87, 155 - 162 (1991)

8 Nakazawa H, Hori M, Ozaki $\mathrm{H}$ and Karaki H: Mechanisms underlying the impairment of endothelium-dependent relaxation in the pulmonary artery of monocrotaline-induced pulmonary hypertensive rats. Br J Pharmacol 128, 1098 - 1104 (1999)

9 Todorovich-Hunter L, Johnson DJ, Ranger P, Keeley FW and Rabinovitch M: Altered elastic and collagen synthesis associated with progressive pulmonary hypertension induced by monocrotaline. A biochemical and ultrastructural study. Lab Invest 58, $184-195$ (1988)

10 Kolpakov V, Gordon D and Kulik TJ: Nitric oxide-generating compounds inhibit total protein and collagen synthesis in cultured vascular smooth muscle cells. Circ Res 76, 6305-6309 (1995)

11 Xue C and Johns RA: Upregulation of nitric oxide synthase correlates temporally with onset of pulmonary vascular remodeling in the hypoxic rat. Hypertension 28, $743-753$ (1996)

12 Mathew R, Gloster ES, Sundararajan T, Thompson CI, Zeballos GA and Gewitz MH: Role of inhibition of nitric oxide production in monocrotaline-induced pulmonary hypertension. J Appl Physiol 82, 1493 - 1498 (1997)

13 Takenaka T, Ogawa $\mathrm{Y}$ and Tobishi $\mathrm{K}: \mathrm{Ca}^{2+}$-induced contraction and hyperreactivity of pulmonary arterial smooth muscle in monocrotaline-treated rats. Jpn Circ J 54, 515 - 523 (1990)

14 MacLean MR: Pulmonary hypertension, anorexigens and 5-HT: pharmacological synergism in action? Trends Pharmacol Sci 20, 490 - 495 (1999)

15 Giaid A, Yanagizawa M, Langleben D, Michel RP, Levy R, Shennib H, Kimura S, Masaki T, Duguid WP and Stewart DJ: Expression of endothelin-1 in the lungs of patients with pulmonary hypertension. N Engl J Med 328, 1732 - 1739 (1993)

16 Mathew R, Zeballos GA, Tun H and Gewitz MH: Role of nitric oxide and endothelin-1 in monocrotaline-induced pulmonary hypertension in rats. Cardiovasc Res 30, 739 - 746 (1995)

17 Miyauchi T, Yorikane R, Sakai S, Sakurai T, Okada M, Nishikibe M, Yano M, Yamaguchi I, Sugishita Y and Goto K: Contribution of endogenous endothelin 1 production in rats with pulmonary hypertension. Circ Res 73, 887 - 897 (1993)

18 Suzuki H and Twarog BM: Membrane properties of smooth muscle cells in pulmonary hypertensive rats. Am J Physiol 242, H907 - H915 (1982)

19 Ito KM, Sato M, Ushijima K, Nakai M and Ito K: Alterations of endothelium and smooth muscle function in monocrotalineinduced pulmonary hypertensive arteries. Am J Physiol 279, H1786 - H1795 (2000)

20 Ozaki H, Sato K, Satoh T and Karaki H: Simultaneous recording of calcium signals and mechanical activity using fluorescent dye fura 2 in isolated strips of vascular smooth muscle. Jpn J Pharmacol 45, 429 - 433 (1987)

21 Meininger GA and Davis MJ: Cellular mechanisms involved in the vascular muscular response. Am J Physiol 263, H647H659 (1992)

22 Sparks HV: Effect of quick stretch on isolated vascular smooth muscle. Circ Res 14/15, Suppl 1, I254 - I260 (1964)

23 Uchida E and Bohr DF: Myogenic tone in isolated perfused resistance vesicle from rats. Am J Physiol 216, $1343-1350$ (1969)

24 Harder DR: Pressure-dependent membrane depolarization in cat middle cerebral artery. Circ Res 55, 197 - 202 (1984)

25 Nelson MT, Conway MA, Knot HJ and Brayden JE: Chloride channels blockers inhibit muscular tone in rat cerebral arteries. J Physiol (Lond) 502, 259 - 264 (1997)

26 Yamazaki J, Duan D, Janiak R, Kuenzli K, Horowitz B and Hume JR: Functional and molecular expression of volumeregulated chloride channels in canine vascular smooth muscle cells. J Physiol (Lond) 507, 729 - 736 (1998) 